\title{
Hatékonyabban támogatja-e a könnyen érthetö üzenet az értelmileg akadályozott tanuló fözési folyamatát a sztenderd üzenetnél?
}

\begin{abstract}
Magyarországon az értelmileg akadályozott tanulók általános iskolájában, a 6. osztályban kötelezően oktatandó ismeretkör a zacskós leves készítése. Felvetődik a kérdés, vajon képesek-e a 6. osztályos tanulók a zacskós levest a tasakon olvasható leírás alapján elkészíteni? Vajon segítséget jelent-e nekik a tanulási folyamatban, ha a zacskós leves elkészítésének folyamatát könnyen olvasható és érthető formában is rendelkezésre bocsátjuk?

$\mathrm{Az}$ empirikus kutatást - az érintett tanulók és szüleik írásos beleegyezésével - egy dél-alföldi szegregált iskolában végeztük el. A kutatásba 8 értelmileg akadályozott tanulót vontunk be. A zacskós levest 4 fö először a tasakon olvasható leírás, majd egy hónappal később a tanulmány szerzője által készített könnyen olvasható és érthető leírás alapján készítette el. 4 fö fordított sorrendben dolgozott. A könnyen érthető szöveges-fényképes és csak fényképes, 30 lépésből álló folyamatot bemutató recepthez a valós helyszínen készültek a fényképek. A fözési folyamat eredményességét nyilvánvalóan nem csak a recept érthetősége befolyásolja. Annak érdekében, hogy más tényezőket jó eséllyel kizárjunk, közel azonos jellemzőkkel bíró tanulókat választottunk ki. Figyelembe vettük a tanulók nyelvi kompetenciájának szintjét (tud-e olvasni), a zacskós leves készítésével kapcsolatos előzetes ismereteiket (P-A-C teszt, gyógypedagógusi interjúk, személyes megfigyelés).

A teljes fözési folyamatról videofelvétel készült. A videofelvételeket elemezve látjuk, hogy a zacskós levest a kutatásban részt vevő tanulók a tasakon lévő recept alapján, további segítség nélkül nem tudják elkészíteni. Ugyanakkor a második fözés attól függetlenül sikeresebb, hogy az első fözést a tasakon lévő vagy a könnyen olvasható és érthető recept alapján teljesítették a tanulók. A gyakorlásnak, az ismétlésnek tehát nagyobb szerepe lehet, mint magának az érthetőségnek. Ugyanakkor a könnyen olvasható és érthető recept alkalmazása egyrészt láthatóan nagyobb sikerélményt biztosít, másrészt hatékonyabban segíti elő a tanulási folyamatot a sok nehézséget és kudarcélményt okozó tasakon lévö recept alkalmazásával szemben.
\end{abstract}

Kulcsszavak: könnyen érthető kommunikáció, érthetőség, kerettanterv, felső tagozat, kutatási eredmények, zacskós leves készítése

\section{BEVEZETÉS}

A tanulmány a könnyen érthető kommunikáció témája köré épül. Munkám során arra vállalkozom, hogy egy eredeti, zacskós levesen található elkészítési útmutató leírásának értelmezését összevessem ugyanazon zacskós leves könnyen érthető elkészítési útmutatójának érthetőségével. Magyarországon ilyen jellegű kutatás még nem született. Így különösen motivált vagyok arra, hogy a kutatási eredményekkel segítsem az értelmileg akadályozott személyek életét.

Elengedhetetlennek tartom, hogy a könnyen érthető kommunikációról teljes és valós képet kapjunk. Szeretnénk azt hinni, hogy a könnyen érthető kommunikáció minden értelmileg akadályozott személy számára megfelelő, jól alkalmazható módszer: ennek tudományos bizonyítására azonban eddig Magyarországon nem került sor.

Ebben a tanulmányban az elvégzett kutatás módszertanát, az általam készített könnyen érthető anyagokat mutatom be. Az eredményeket egy svájci konferencián ismertetem 2021 augusztusában. 


\section{VÁZLATOS SZAKIRODALMI ÁTTEKINTÉS}

\section{A célcsoport megjelölésére használt fogalmakról}

A gyógypedagógiában használatos fogalmak az évek során folyamatosan változáson mennek keresztül. Itt és most az általam vizsgált célcsoport meghatározásának egyik változatát mutatom be.

„Az értelmi akadályozottságot (értelmi fogyatékosság egyik részcsoportját) egy három egységből álló fogalomként foghatjuk fel az egyéni károsodással, mely tanulási és fejlődési korlátozottsághoz vezet, és társadalmi hátrányokat von maga után. Az ilyen lineáris szemlélet azonban ma már nem megfelelően jellemzi az értelmi fogyatékosság/akadályozottság jelenségét. A valóságban mindig kölcsönhatásokkal és cirkuláris folyamatokkal találkozunk, úgy, hogy a biológiai, pszichikai és szociális tényezők kölcsönös együtthatásából kell kiindulni" (Hatos, 2015:8).

Jelen tanulmányban a célcsoport megnevezésére az értelmileg akadályozott, illetve az értelmi sérült kifejezést használom. Némely esetben, amikor szó szerint idézek, nem tudok eltekinti az eredeti szövegben megfogalmazottaktól.

\section{Emberi jogi alapok}

A Fogyatékossággal élő személyek jogairól szóló ENSZ egyezményt kihirdető 2007. évi XCII. törvény a fogyatékos személyek - beleértve az értelmileg akadályozott személyeket is - jogairól szól: „...célja valamennyi emberi jog és alapvető szabadság teljes és egyenlő gyakorlásának előmozdítása, védelme és biztosítása valamennyi fogyatékossággal élő személy számára, és a velük született méltóság tiszteletben tartásának elömozdítása" (fogyatékosságügyi ENSZ egyezmény 1. cikk).

Ha különböző fogyatékossági típusokra gondolunk, általános kép él az emberek fejében arról, kit hogyan közelítünk meg, kihez milyen módon tudunk közelebb férkőzni. Tudjuk, hogy a siket és nagyothalló emberekkel jobbára jelnyelvvel kommunikálunk, a vak és gyengénlátó emberek Braille-írást használnak, sőt a különböző augmentatív és alternatív kommunikációt kínáló eszközök is egyre elterjedtebbé válnak. De mi a helyzet az értelmileg akadályozott személyekkel? „Jó lenne, ha (...) legalább ugyanennyire ismertté és alkalmazottá válna az értelmi sérült emberek tájékozódását segítő könnyen érthető kommunikáció" (Horváth, 2017a:9).

„Az ENSZ fogyatékossággal élő személyek jogairól szóló egyezményét és annak fakultatív jegyzőkönyvét Magyarország az elsők között írta alá 2007-ben és ezután a XCII. törvénnyel ratifikálta is (...) Az államok olyan rendelkezések és intézkedések törvénybe iktatására kötelezik magukat, amelyek elősegítik a fogyatékossággal élő emberek jogainak érvényesülését" (Farkasné Gönczi \& Graf-Jaksa, 2009:84-85).

Az egyezmény 9 . cikke ír a fogyatékossággal élő személyek önálló életvitelét (és társadalmi részvételüket) segítő intézkedésekröl. Ilyen intézkedések „a fizikai környezethez, a közlekedéshez, az információhoz és kommunikációhoz, beleértve az információs és kommunikációs technológiákat és rendszereket, valamint más nyilvánosan hozzáférhető vagy rendelkezésre álló lehetőségekhez és szolgáltatásokhoz való hozzáférést, mind a városi, mind vidéki területeken" (fogyatékosságügyi ENSZ 
egyezmény 9. cikk). Ebben a cikkben esik szó a könnyen érthető kommunikációról is, melynek értelmében biztosítani kell a könnyen érthető és olvasható jelzéseket az értelmileg akadályozott személyek számára.

A 21. cikk arról szól, hogy a fogyatékossággal élő személyek számára az általuk választott kommunikációs formát, eszközöket és módozatot kell biztosítani.

Ahogyan a fogyatékosságügyi ENSZ egyezmény 29. cikkéböl kiderül, a könnyen érthető kommunikációval olyan, az ember jogait érvényre juttató tevékenységekhez való hozzáférést is igyekeznek biztosítani, mint a politikai és közéletben való részvétel.

\section{A könnyen érthetö kommunikáció meghatározása}

Farkasné Gönczi (2018:70) szerint „a könnyen érthetö kommunikáció a köznyelvben megjelenő információ fontos tartalomegységeinek megjelenítése, vagy önálló információs tartalom kidolgozása egyszerü, letisztult formában, mely az információ megértését szolgálja. Az információ könnyen érthető kommunikáció alkalmazásával történő feldolgozását az adaptáció tartalmi és formai szabályainak betartása mellett a képek és illusztrációk adekvát alkalmazása segíti."

Horváth (2019:63) megfogalmazása alapján „a könnyen érthetö üzenet kódolása alatt azt a folyamatot értjük, amikor a közlő a beszélt, az írott, a képi vagy a filmes üzenetét az üzenet befogadójának, azaz az értelmi sérült személynek a dekódolási, azaz az üzenet észleléséhez, érzékeléséhez és értelmezéséhez szükséges kompetenciájához illeszkedő, írott kódolási szabályok szerint fogalmazza meg."

\section{A könnyen érthetö kommunikáció az értelmileg akadályozott tanulók oktatásához készített keret- tantervekben}

Kutatásomban a zacskós leves tényleges elkészítésével vizsgálom a könnyen érthetőnek és olvashatónak szánt anyag és az eredeti, a zacskós leves zacskóján olvasható leírás érthetőségét.

A kommunikáció; a számolás-mérés; a játékra nevelés; a társadalmi ismeretek; az önkiszolgálás; a technika, életvitel és gyakorlat; a környezetismeret; az ének-zene; az ábrázolás-alakítás; az információs eszközök használata; a mozgásnevelés és a testnevelés tantárgyakhoz készített kerettantervek olvasása során egy alkalommal sem találkoztam sem a „könnyen érthető”, sem az „egyszerüen érthető” kifejezésekkel. Az olvasás-írás tantárgy kerettantervének elemzése során bukkantam rá kizárólag az alábbi szövegrészletre: „A középsúlyos értelmi fogyatékos tanuló esetében a pedagógusok feladata elérni, hogy az életkornak és az egyéni képességeknek megfelelő olvasási és írási technikák folyamatos fejlesztésével és alkalmazásával a tanuló legyen képes az információkat elemi szinten megszerezni, átadni, legyen képes könnyen érthetö, rövid szöveg elolvasására, értelmezésére, néhány egyszerü gondolat leírására egyre kevesebb segítséggel" (olvasás-írás kerettanterv 1-8. osztály, 2020:1).

Az olvasás-írás tantárgy kerettantervében az általános iskola 5-6. évfolyamán, az értő olvasás témakörben jelenik meg a zacskós leves készítése mint fejlesztési 
feladat (olvasás-írás kerettanterv 1-8. osztály, 2020:19). Tény, hogy az elnyújtott betűtanítás miatt ezen az osztályfokon még nem minden betút ismernek a tanulók, így ez a feladat irrelevánsnak bizonyul. Ez is egy oka annak, hogy kutatásomba nem a 6., hanem a 7-10. évfolyamon tanulókat vontam be.

Azért választottam tehát éppen a zacskós leves elkészítését, mert ez az ismeret szerepel a kerettantervben. Egyúttal az általam készített könnyen érthető elkészítési útmutatóval példát tudok mutatni a kerettantervben megjelenő alapelv gyakorlati megvalósítására.

\section{Könnyen érthető receptek a konyhában}

„Az értelmileg akadályozott gyermekek és felnőttek társadalmi életben való aktív és egyenjogú részvételének egyik fontos feltétele, hogy eljussanak hozzájuk az írott és a hangzó információk és megérthessék azokat; ily módon képesek legyenek tájékozódni az öket körülvevő világban" (Horváth, 2017b:23).

Éppen ezért szeretnék szerepet vállalni abban, hogy az értelmileg akadályozott személyek megismerkedhessenek a konyhával, hozzásegíteni őket ahhoz, hogy egyszerü - vagy akár bonyolultabb - ételeket is elkészíthessenek.

Magyarországon Farkasné Gönczi (2019) hozott létre egy blogot, melyen bárki másodpercek alatt hozzáférhet könnyen olvasható és érthető receptekhez. A honlapon egyszerüen kezelhetően, kategóriákba sorolva találhatók meg a különböző ételcsoportok. A szerző igyekszik „egyszerü megfogalmazással és instrukciókkal, lépésekre bontva, a konyhai tevékenységek könnyebb érthetősége kedvéért képekkel segítve" (Szebelédi-Kurucz, 2012:286) leírni a különböző ételek elkészítésének folyamatát.

\section{MEGELŐZő KUTATÁSI TAPASZTALATOK A KÖNNYEN ÉRTHETŐ ANYAGOK ÉRTHETŐ- SÉGÉNEK VIZSGÁLATA TÉMAKÖRÉBEN}

Az Egyesült Királyságban Sutherland és Isherwood 2016-ban készített egy szisztematikus szakirodalmi áttekintést. Adott elektronikus adatbázisokból szisztematikus módon gyűjtött források meghatározott elemzési szempontok szerinti áttekintése során azt találták, hogy 2013 novembere és 2014 januárja között 11 publikáció született, amelyekben megkísérlik felmérni a könnyen érthető kommunikáció hatékonyságát. A tanulmány legfontosabb megállapítása, hogy vannak már olyan bizonyítékok, amelyek alátámasztják, az értelmi sérült személyek esetében a könnyen érthető anyagokkal hatékonyabban tudjuk az információt átadni, mint a sztenderd szövegekkel. Az azonban még nem egyértelmü, hogy például a szimbólumok, képek (vonalrajzok) és fényképek használata is támogatja-e az értelmezés folyamatát. Ugyanakkor a fényképek kizárólagos használata előnyös lehet az értelmi sérült emberek egyes csoportjai számára. A könnyen érthető üzenetek készítésének támogatására létrejött szabályrendszerek által javasolt, a kiadványok arculatára vonatkozó szabályok betartásának szükségességét azonban kevés bizonyíték támasztja alá. 


\section{A VIZSGÁLAT MÓDSZERTANA}

\section{A kutatási kérdés}

Nem állítottam fel hipotézist, helyette kutatási kérdést fogalmaztam meg. „A jó hipotézis fontos tulajdonsága, hogy lehetöség szerint új ismeretek, megközelítések felé mutat, meghaladja a korábbi ismereteket, vagy megkérdőjelezi azokat" (Boncz, 2015:20). Magyarországon azonban ilyen jellegű kutatás még nem született, így kevéssé tűnt helyes útnak a hipotézis felállítása. A kutatás során tehát arra a kérdésre keresem a választ, hogy az értelmileg akadályozott tanulók fözési folyamatát hatékonyabban támogatja-e a könnyen érthető recept a sztenderd receptnél?

\section{A kutatás alanyai}

Kutatásom során értelmileg akadályozott tanulók körében vizsgálom a könnyen érthető kommunikáció hatékonyságát. Mint később kiderült, a kutatás megkezdése előtt kialakított tervem több ponton is változtatást igényel. Az alábbiakban az eredeti tervemet mutatom be. A felmerült problémákat és az ezeknek okán történő változtatásokat „A kutatás tényleges előkészítését befolyásoló tényezők” című fejezetben foglaltam össze.

Az alapsokaságból nem valószínüségi mintaválasztással jelöltem ki a bevont személyeket. A kiválasztásnál figyelembe vettem a tényt, hogy értelmileg akadályozott tanulók számára íródott kerettantervben, az általános iskola 5-6. évfolyamán jelenik meg a zacskós leves készítése az olvasás-írás tantárgy keretein belül.

A kutatás megvalósíthatósága érdekében, a létező kapcsolati hálómra tekintettel, valamint a korábban szerzett megannyi jó tapasztalatom miatt a hódmezővásárhelyi Kozmutza Flóra Óvoda, Általános Iskola, Szakiskola, Kollégium, Egységes Gyógypedagógiai Módszertani Intézményre esett a választásom. A kutatásban részt vevő értelmileg akadályozott tanulókat tudatosan választottam ki.

Az eredeti elgondolás szerint, a kerettantervi előírásoknak megfelelően, a felső tagozatos értelmileg akadályozott tanulók képezték a célcsoportot.

Célom az volt, hogy a mérésbe az alábbiakban bemutatásra kerülő két változó (nyelvi kompetencia, előzetes tudás) mentén hasonló tulajdonságokkal rendelkező személyek kerüljenek. Így 20 tanulót szerettem volna bevonni a mérésbe, akik közül azt a 10 tanulót szándékoztam bevonni a kutatásba, akik azonosnak vagy közel azonosnak mondható nyelvi kompetenciával és előzetes tudással rendelkeznek. Első lépésként, a Pedagógiai Analízis és Curriculum (P-A-C) mérőeszközzel szándékoztam a tanulók előzetes nyelvi kompetenciáját felmérni. Mivel magához a zacskós leveshez, egyáltalán a konyhai munkához kapcsolódó előzetes tudást is szándékomban állt megismerni, így a tanulókkal foglalkozó gyógypedagógusoktól félig strukturált interjú formájában volt célom információkat gyűjteni. A tanulókról kialakítandó kép érdekében szerettem volna előzetesen rögzített szempontok alapján megfigyelni azt a folyamatot is, amikor a tanulók a zacskós levest a gyógypedagógus irányítása mellett készítik el. Arra is tekintettel voltam hogy a megfigyelésre nem biztos, hogy lehetőségem lesz, így ezt eleve többletinformációnak tekintettem. Miután kellő adat 
állt volna a rendelkezésemre a tanulók nyelvi kompetenciájáról és a zacskós leves készítésével összefüggő előzetes tudásukról, a 20 tanulóból ki tudtam volna szürni azt a 10 tanulót, akinek a legközelebb esik egymáshoz a nyelvi kompetenciája és az előzetes tudása.

A kísérletbe végül 8 tanulót tudtam bevonni. Ennek okát később „A kutatás tényleges előkészítését befolyásoló tényezők" címü fejezetben fejtem ki.

4 tanuló először a zacskós levesen olvasható, a másik 4 tanuló pedig a könnyen érthető leírás alapján készítette el az ételt. Négy hét elteltével a főzést megismételték, ahol az első 4 tanuló most a könnyen érthető, a másik 4 tanuló pedig az eredeti szöveg alapján fözött.

\section{A kutatás módszere}

A kvalitatív kutatás egyik lényeges tulajdonsága, hogy a kutatást vezető személy magaviselete, feltett kérdései, megnyilvánulásai, nyitottsága újabb kérdések felvetésére adnak lehetőséget; az ezekre adott válaszok újabb és újabb adatokkal szolgálhatnak (Sántha, 2009). A kvalitatív kutatási módszerek közül a megfigyelésen (egyfajta kísérleti helyzeten) alapuló összehasonlító elemzés módszerét alkalmaztam. A természetes kísérletet a tanteremben, vagy egy másik, tanulásra alkalmas helyen végzik; ezért választottam én is a tankonyhát. Ha az eredményeket a pedagógiai gyakorlatban később hasznosítani szeretnénk, akkor fontos, hogy ügyeljünk a minél természetesebb környezet kialakítására (Ivanović, 2016). Ezt az elvet figyelembe vettem én is, így a hódmezővásárhelyi intézmény tanulói számára kialakított és jól ismert tankonyha szolgált a kutatás helyszínéül.

\section{A kutatás eszközei}

\section{Eredeti zacskós leves - Dörgicsei csibeleves}

A kutatás megkezdése előtt szükségszerű volt meghatározni azt is, milyen ételt fognak a tanulók elkészíteni: a kerettantervnek megfelelően zacskós levesre volt szükségem. A boltban megvásárolható sokféle zacskós leves szolgált alapsokaságként. Azt, hogy pontosan melyik zacskós levest választottam ki, véletlenszerủ volt. Arra azonban figyeltem, hogy két különböző - egy bögrés és egy túzhelyhasználatot kívánó, edényben készült - zacskós levest válasszak. A két véletlenszerűen kiválasztott darabot elvittem az intézménybe, majd a bevont gyógypedagógusok véleményét kikértem. Ettől a ponttól kezdve szakértői mintaválasztással dőlt el, hogy a két leves közül melyikkel fogunk a továbbiakban dolgozni. A kiválasztás során a gyógypedagógusok korábbi tapasztalataira támaszkodtam, akik figyelembe vették a tanulók képességeit, előzetes ismereteit. A döntésben leginkább az kapott szerepet, hogy a bögrés leves elkészítése finomabb, precízebb mozdulatokat igényel, kisebb eszközökkel kell dolgozni, így ez - a tapasztalatok szerint - nehezebbnek bizonyul. Az imént felsoroltak alapján végül a tűzhelyhasználatot kívánó, edényben készülő Dörgicsei csibeleves mellett döntöttünk.

Meglátásom szerint a Dörgicsei csibeleves zacskóján olvasható leírás egyrészt apró betűs, tehát nehezen olvasható. Másrészt nem elég részletes, az olvasótól/ 
készítőtől előzetes tudást feltételez. Maga az útmutató szorosan az egyéb leírások, reklámok mellett található, így a zsúfoltságtól nehezen lehet tájékozódni a felületen. Bár maga az útmutató valamivel nagyobb betủméretü, mint az oldalon található más leírások, véleményem szerint ez mégsem segíti kellőképpen az egyént. A magyarázat kiegészítéseként szolgáló képek részben felelnek meg a szövegnek. A lényeges lépéseket ugyan bemutatják, de számos egyéb teendő rejtve marad. A dőlt, nem szabályos betűk és számok szintén nehezítik az olvasást, illetve ezáltal a megértést.
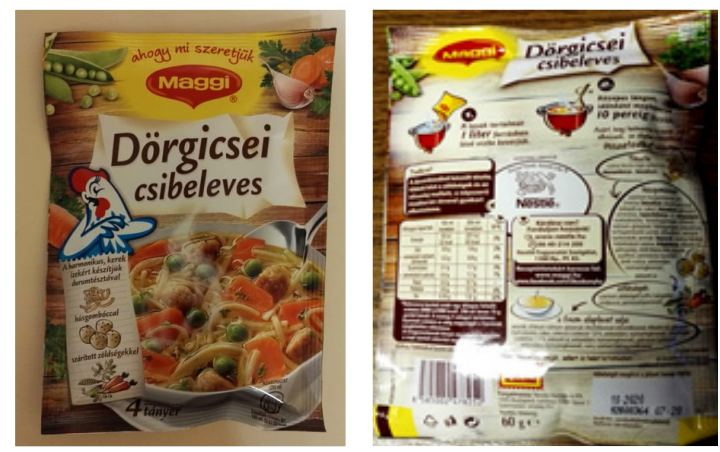

1-2. kép. A zacskós leves tasakjának első és hátsó oldala

\section{Szöveges-képes könnyen érthető recept}

A szöveges-képes receptet magam állítottam össze. A szöveget a könnyen érthető üzenet készítésének írott szabályaira figyelemmel készítettem el. Arial betűtípust, 2-es sorközt használtam. Bár a betủmérettel kapcsolatban a lektorálás során (lásd: lejjebb) erre nem kaptam javaslatot, a 14-es méretet végül 16-ra cseréltem. A címet, illetve az alcímet 18-as betűmérettel, félkövér betűvel készítettem. Az anyagot a könnyebb érthetőség érdekében egészítettem ki képekkel, valamint figyelembe vettem azt is, hogy az eredeti leírásban is látható kép. Az általam készített anyagban található képeket magam fotóztam, valós helyszínen készítettem, abban a tankonyhában, ahol a tanulók a megfigyelés során az ételt ténylegesen elkészítették. Ezt azért tartom kiemelten fontosnak, mert így a tanulóknak nem kell elvonatkoztatniuk a látottaktól, a fotón található konkrét eszközöket kell a fözés során is használniuk. Ez kizárja annak a lehetőségét, hogy a tanulók az absztrakciós képesség hiánya miatt ne tudják a feladatot végrehajtani. Törekedtem továbbá arra is, hogy a képeken ne legyen zavaró háttértényező, kellő megvilágítás legyen, és egyértelmű mozzanatokat ábrázoljak. Fontos szempont volt még, hogy jó minőségủ képek szülessenek, melyek a nyomtatás után is jól láthatóak, elég nagyméretűek. Fokozottan ügyeltem arra is, hogy a nyilak mindig a mutató névmásból kiindulva a megfelelő helyre mutassanak, egyértelműek legyenek.

Munkám során a könnyen érthető kommunikáció egyik fontos alapelvét, a bevonás elvét is követtem (Horváth, 2017a). Az elkészült könnyen érthető anyag érthetőségét az ÉFOÉSZ önérvényesítő munkatársa, Sallai llona (továbbiakban: ellenőr) lektorálta. Az ellenőr számos korábbi tapasztalattal rendelkezik a könnyen érthető üzenetek lektorálása terén, így kellő segítséget tudott nyújtani számomra. Az egyez- 
tetésre nem személyesen, hanem e-mailen került sor: erre a szükös időkeret és a lakóhelyeink közötti nagy távolság miatt volt szükség. Bár úgy gondolom, együttmúködésünk hatékony volt, nem zárkóznék el attól, hogy a későbbiekben a hasonló teendőket személyes úton intézzük, hiszen nyilvánvalóan egyszerübb szóban megfogalmazni - mindkét félnek - a meglátásokat, véleményeket, gondolatokat.

Az ellenőr jelen esetben csak néhány építő kritikát fogalmazott meg, melyeket figyelembe véve a célnak inkább megfelelö, hatékony eszközt tudtam készíteni. Felhívta a figyelmemet például arra, hogy az egyenlőségjelet cseréljem ki a „vagyis” kifejezésre, illetve megkért, hogy néhány helyen a folyamatot bontsam tovább, és ennek megfelelően több lépésben ábrázoljam azt (konkrétan: „Tedd az edényt a túzhelyre.” „Vedd le az edényt a túzhelyröl.”).

A szöveges-képes könnyen érthető receptet az 1. számú mellékletben csatolom.

\section{Képes könnyen érthető recept}

A kutatás során felmerülő nehézségek miatt (lásd: A kutatás tényleges előkészítése című alfejezet) szükségessé vált a nem olvasó tanulók számára a szöveg nélküli, képes könnyen érthető recept elkészítése.

A csak képes folyamat-ábrázolás készítése során ugyanazokat az elveket, szabályokat vettem figyelembe, mint amelyeket a szöveges-képes változat készítésekor, és ugyanazokat a képeket használtam mind a két verzióban. Ezen anyag készítése közben még inkább bebizonyosodott számomra, milyen fontos, hogy konkrét képeket használjak, hiszen egyetlen kép alapján a tanulónak fel kell ismernie, milyen cselekvést várok el töle. Az eszközöket és az elkészítési folyamatot ábrázoló képeket sorszámokkal jelöltem. Ügyeltem arra, hogy ez a két csoport jól elkülöníthető, könnyen értelmezhető legyen, így a nyomtatott változatban egy piros lapot tettem közéjük.

Az ellenőr a képes könnyen érthető recept esetében nem tett javaslatot, kiegészítést.

\section{Szöveges-képes leírás a csap használatához}

A kutatás elökészítése során felmerült a kérdés, mi történik, akkor, ha a tanuló nem tudja használni a tankonyhában található csapot? Ennek okán készült el a szöveges-képes leírás, mely a csap használatát magyarázza. A szöveget szintén a könynyen érthetö üzenet készítésének szabályai alapján írtam. Arial betūtípust, 2-es sorközt, a korábbi 14-es helyett 16 -os betüméretet használtam. Az ellenőr javaslatára címet adtam az anyagnak, melyet 18-as betűmérettel, félkövér betűvel készítettem. Ugyanúgy, ahogy a receptnél, itt is a valós helyszínen, a megfigyelésnek helyet adó tankonyhában készítettem fotókat, melyekkel a könnyen érthető szöveget kiegészítettem. A fotókra vonatkozó, előzetesen ismertetett szabályok betartása ez alkalommal is megvalósult. Jelen esetben is törekedtem arra, hogy a mutató névmásból kiindulva, egyértelmű nyilakkal magyarázzak. A nyitás és a zárás mozdulatának irányát nyilakkal is szemléltettem.

Az ellenőr javaslatára a „Fogd meg a csapot.” mondat helyett a „Fogd meg a csap karját.” leírás szerepel a végleges változatban. Állítása szerint jobban értelmezhető a mondandóm, ha konkrétumot írok, mert neki a csap szóról az egész csap jut eszébe. Mivel jogosnak tartottam a meglátását, természetesen javítottam. Ugyanezt a ja- 
vítást megtettem az „Emeld fel a csapot.”, valamint a „Nyomd le a csapot.” mondatnál is. Az ellenőr további javaslata az volt, hogy jelenjen meg az is: nem csak az általam bemutatott csapfajta létezik. Ennek megfelelően kiegészítést tettem arra vonatkozóan is, hogy ugyan többféle csap létezik, de én most ezt a fajta csapot mutatom be. Az ellenőr véleménye szerint célszerű lett volna bemutatni a víz hőfokának a szabályozását is. Tekintve azt, hogy konkrét, általam ismert értelmileg akadályozott személyek számára készült a leírás, úgy gondoltam, ez a magyarázat bonyolította volna annak a cselekvésnek a megértését, melyet elvártam a tanulóktól. Jelen helyzetben nem volt célom magyarázni azt, hogyan kell a víz hőfokát szabályozni, így az erre vonatkozó javaslatot nem fogadtam meg.

Itt szeretném megemlíteni azt, hogy bár az ellenőr nagyon sok segítséget nyújtott a munkám során, az ő képességei nem tükrözik azoknak a személyeknek a képességeit, akikkel a kutatási folyamatban dolgoztam. Hasznosnak tartanám, ha lehetőség lenne arra, hogy különböző nyelvi és kognitív képességekkel rendelkező lektorokkal tudjunk dolgozni, hiszen így biztosítható leginkább az ellenőrzés hatékonysága.

A csap használatának szöveges-képes leírását a 2. számú mellékletben csatolom.

\section{Képes leírás a csap használatához}

Annak tudatában, hogy a részt vevő 8-ból 4 tanuló nem olvas (lásd: A kutatás tényleges előkészítése című alfejezet), ez esetben is szükségszerű volt a csap használatának csak képekkel való bemutatása.

Ennek az anyagnak az elkészítése közben is a szöveges-képes változatban használt, a kísérlet helyszínén általam készített képeket alkalmaztam. Törekedtem arra, hogy minél egyértelműbb mozzanatokat mutassak be, így csupán három képben magyaráztam a csap használatát. Az általam végzett és a tanulóktól elvárt mozdulat irányát nyilakkal is szemléltettem. A képes leírás az imént bemutatott szöveges-képes leírással megegyezik, a különbség a szöveg meglétében van.

\section{Pedagógiai Analízis és Curriculum}

A kutatási folyamatban a Günzburg által kifejlesztett Pedagógiai Analízis és Curriculum (P-A-C) felmérő eszközt terveztem még alkalmazni. A P-A-C lehetővé teszi a meglévő és hiányzó készségek felmérését, láthatjuk a viselkedés gyengeségeit és erősségeit. „A P-A-C eljárás célja, hogy minőségi képet nyújtson a szociális kompetencia erősségeiről és gyengéiről, szemben a mennyiségben kifejezett teszt ponttal (Günzburg, 2000:18). A pedagógiai diagnosztikai eszköz négy területet mér fel - az önkiszolgálást, a kommunikációt, a szocializációt és a tevékenységet. A felsorolt területek közül a kommunikációra vonatkozó itemek eredményeit állt szándékomban felhasználni a megfigyelési szakaszba kerülő tanulók kiválasztására. Így a vizsgálatba eredetileg bevonni tervezett 20 föből tudtam volna kiválasztani olyan 10 föt, akiknek közel azonos a nyelvi kompetenciája. Ezzel kizárhattam volna azt, hogy a kétféle szövegtípus megértése közötti különbséget a tanulók eltérő nyelvi kompetenciájával lehessen magyarázni. 


\section{Interjú-kérdéssor}

A tanulók zacskós leveshez, illetve a konyhai munkához kapcsolódó előzetes tudását is szerettem volna feltérképezni. A főzési folyamat során alkalmazott eredeti leírás és a könnyen érthető leírás értelmezését ugyanis befolyásolhatja az előzetes tudás és előzetes tapasztalat is. Szerettem volna kizárni ezt a változót is. A cél az volt, hogy közel azonos elözetes tudással és elözetes tapasztalattal rendelkező tanulót választhassak be a megfigyelési helyzetbe. Ennek érdekében készítettem el egy interjú-kérdéssort, melyet a tanulókkal foglalkozó gyógypedagógusokkal állt szándékomban feltenni. Meg szerettem volna tudni, hogy a tanuló készített-e már korábban zacskós levest; ha igen, akkor milyen eredményességgel, illetve ez otthon vagy az iskolában történt.

A kérdések megfogalmazása során törekedtem arra, hogy minél több információt megtudjak a tanuló ételkészítéshez való hozzáállásáról, tapasztalatairól, tudásáról. Fontosnak tartottam továbbá, hogy információt gyűjtsek a tanuló kommunikációjáról, így ezzel kapcsolatban is fogalmaztam meg kérdéseket. Ez többek között segítséget nyújtott abban, hogy megállapítsam, a tanulónak a szöveges-képes vagy a képes könnyen érthető anyagra lesz szüksége a megfigyelés során.

Fontos megjegyezni, hogy tisztában voltam azzal, a tervezett interjú során kapott információ nem feltétlenül megbízható, hiszen előfordulhat, hogy a tanuló bár többször is készít otthon ételt, erről nem számol be az iskolában.

\section{Megfigyelési szempontok}

A kutatás előkészítése során szándékomban állt a gyógypedagógus irányítása alatt a zacskós leves elkészítését megfigyelni az érintett tanulók körében. Ezt azért tartottam volna szükségesnek, mert szerettem volna a nem a „receptek" értelmezésböl következő, de a fözési folyamatot befolyásoló tényezőket kizárni (például a cselekvések kivitelezésével kapcsolatos problémákat).

A megfigyelési szempontok megfogalmazása során kiemelten figyeltem arra, hogy magára a zacskós leves elkészítésére, a tanuló hozzáállására, tudására fókuszáljak. Szerettem volna információt gyűjteni arról, hogy a gyógypedagógus jelenléte, a társak jelenléte, esetleg a magam mint kívüláló jelenléte mennyire befolyásolhatja a munkát. Ezen információk birtokában reálisabban láthattam volna a tanuló megfigyelés során tanúsított magatartását, megfigyelhettem volna, hogy a tanuló milyen szintű motiválást igényel, egyáltalán igényel-e. A megfigyeléseim lejegyzéséhez egy táblázatot is készítettem.

\section{Utasítások}

A tanári magyarázatból nyert információ is befolyásolhatja a különböző „receptek” értelmezését. Ezt is szerettem volna kizárni. Ezért előzetesen készítettem egy „utasítás-leírást", amelyben azt fogalmaztam meg, amit minden, a megfigyelési helyzetbe kerülő gyermeknek azonos módon mondtam. Ötféle utasítást készítettem el - az eredeti szöveghez, a szöveges-képes könnyen érthetö recepthez, a képes könnyen érthető recepthez, a csap használatának szöveges képes leírásához, a csap használatának képes bemutatásához. Törekedtem arra, hogy a lényegre koncentrálva 
egyszerüen és pontosan fogalmazzak. A séma valamennyi alkalommal ugyanaz volt, csupán néhány változtatást tettem annak megfelelően, hogy melyik folyamatról áll szándékomban instrukciót adni.

Itt szeretném még megemlíteni, hogy a megfigyelési helyzetben nem volt célom azt is felmérni, hogy a tanuló tájékozódik-e a konyhában, megtalálja-e a szükséges eszközöket, ezért minden használatos eszközt a megfigyelés megkezdése előtt a pultra készítettem.

\section{Kutatásetikai megfontolások}

A kutatás céljáról és annak folyamatáról minden érintett szereplő számára készítettem tájékoztató leveleket, az értelmileg akadályozott tanulók számára könnyen érthetően. A kutatás során nyert adatok és információk felhasználhatósága érdekében adatkezelési hozzájáruló nyilatkozat is készült, amit a szülők írtak alá. A tanulók is hozzájárultak ehhez könnyen érthető nyilatkozat formájában.

\section{A kutatás tényleges elökészitését befolyásoló tényezők}

A hódmezővásárhelyi Kozmutza Flóra Óvoda, Általános Iskola, Szakiskola, Kollégium, Egységes Gyógypedagógiai Módszertani Intézmény vezetőjével vettem fel elsőként e-mailen a kapcsolatot. Miután pozitív választ kaptam, megbeszéltünk egy személyes találkozót, melynek során részletesen ismertettem a kutatásomat. Erre az alkalomra magammal vittem valamennyi tájékoztató levelet, illetve hozzájáruló nyilatkozatot és kértem, juttassa el az illetékeseknek.

A kvalitatív kutatások esetében a kutatás alanyaihoz való hozzáférés igen nehéz és időigényes munkafolyamat (Sántha, 2009). A szakértői mintaválasztáshoz szükséges mérések elvégezhetősége érdekében az alapsokaságot jelentő mind a 20 tanuló szülője számára megküldtem a tájékoztató levelet és az adatkezelési hozzájáruló nyilatkozatot. A várakozásokkal ellentétben a 20 helyett mindössze 8 szülő hozzájáruló nyilatkozata érkezett vissza. Így a szakértői mintaválasztás meghiúsult. Bár P-A-C teszt eredményei rendelkezésemre álltak, végül azokat sem használtam. A 8 fős csoportot már nem lehetett tovább szűkíteni. Így mind a 8 főt bevontam a kutatásba: három hetedik, két nyolcadik, egy kilencedik és két tizedik osztályos tanulót, három lányt és öt fiút.

Miután kézhez kaptam a hozzájáruló nyilatkozatokat, felkerestem az érintett gyógypedagógusokat. Praktikus okokból a félig strukturált interjú helyett a gyógypedagógusok írásban válaszoltak a kérdéssorra.

Figyelemmel arra, hogy a főzési folyamat megfigyelésére kiválasztott osztályokban a kutatási időszakban a zacskós leves készítése nem szerepelt a kerettanterv alapján a gyógypedagógusok által készített tematikus tervben, ezért végül a gyógypedagógus irányítása alatt a zacskós leves elkészítésének megfigyelésére sem volt lehetőségem.

Azt, hogy az első megfigyelésre mikor kerül sor, e-mailen egyeztettem a gyógypedagógusokkal. Az alkalmakat a tanítási időre beszéltük meg. Egy tanulóra egy órát szántam, így négy tanulót osztottam be egy napra. Végül ez az első főzés alkalmával két tanuló betegsége miatt három napra bővült. A második alkalommal hasonló okok miatt, szintén három nap leforgása alatt zajlott a főzési folyamat megfigyelése. 
Egy újabb módosítást tettem a megfigyelés rögzítésére vonatkozóan is. A kutatás tervezésekor szándékom az volt, egy állványon fog állni a mobiltelefon, mellyel a videofelvételt rögzítem. Késöbb felmerült, hogy ha a kamera egy ponton áll, kimaradhatnak fontos mozzanatok, ha a tanuló kilép a kamera látószögéből, a részletek - mimika, az ujj vezetése a recepten - nem látszódhatnak. Mindennek okán úgy döntöttem, egy kívülálló személyt vonok be, aki az eseményeket majd rögzíteni fogja. Mivel az öcsémnek van tapasztalata a felvételek készítésében, így egyértelmü volt számomra, hogy őt kérem fel erre a feladatra. Miután vele ezt megbeszéltem, e-mailen jeleztem az intézményvezető asszonynak - akit egyébként folyamatosan tájékoztattam a kutatás állásáról - és a gyógypedagógusoknak változtatási szándékomat. Valamennyien beleegyezésüket adták.

Mivel a szelektálás hiányában nem tudtam azonos nyelvi kompetenciával, hasonló előzetes ismerettel és tapasztalattal rendelkező tanulót kiválasztani, így újabb változtatást tettem. Tekintettel arra, hogy a 8-ból 4 tanuló rendelkezett csak az olvasás képességével, 4 tanuló pedig nem, így vált szükségessé a képes könnyen érthető recept elkészítése is. Ezen a ponton merült fel a csap használatának kérdése is, melynek kapcsán - bár az előzetes tervek között nem szerepelt - elkészítettem a könnyen érthető szöveges-képes és a képes leírásokat.

\section{Módosítások a kísérlet első alkalma után}

Nem titkolt tervem volt, hogy az általam készített könnyen érthető anyagok érthetöségét, hatékonyságát az első főzési alkalmon látott tapasztalataim alapján összegyűjtsem. Egy azonnal szembeötlő problémát valamennyi tanuló esetében érzékeltem. Ez nem volt más, mint hogy az általam kialakított könnyen érthető receptben elöbb szerepelt a leves kevergetése, mint az óra beállítása 10 percre. Ez azt eredményezte, hogy az információnak megfelelően a tanuló elkezdte kevergetni a levest, ám így nem tért át a következő lépésre, és nem teljesítette azt. Így a második főzési alkalomra a két utasítást felcseréltem. Minden tanuló esetében azt tapasztaltam, hogy így gördülékenyebben tudtak egyik lépésről a másikra áttérni.

\section{Megjegyzések}

A megfigyelési helyzetek tapasztalatai alapján fontosnak tartom rögzíteni az alábbiakat.

A könnyen érthető receptek leírásában nem szerepelt, hogy pontosan meddig kell tölteni a vizet az üvegbe. Bár erre vonatkozólag nem tettem módosítást, azt gondolom, ezen célszerủ lenne a jövőben változtatni.

A szöveges-képes könnyen érthető anyagok esetében többször tapasztaltam, hogy a szöveg inkább hátráltat, mint segít. Sokszor előbb nézték meg a tanulók a képeket, az azokon szereplő információ sokszor elegendő is lett volna a tevékenységükhöz.

A szelektálás hiányában különböző képességű tanulók vettek részt a főzési folyamatban. És ez meg is mutatkozott az eltérő főzési teljesítményben, vélhetően az olvasási készség függvényében.

Többször előfordult a zacskó nyitásának nehézsége, mely a legtöbb esetben a finommotorika fejletlenségéből adódott. Több alkalommal nehézséget okozott a könynyen érthető receptről készített füzetben történő lapozás is. 
Ugyanakkor valamennyi tanuló nagyon készségesen állt rendelkezésemre, utasításaimnak eleget téve gördülékenyen tudtunk együtt dolgozni. Azt gondolom, az ő támogató hozzáállásuk nélkül e tanulmány nem jöhetett volna létre.

\section{ÖsSzegzés}

Kutatásom során arra vállalkoztam, hogy egy könnyen érthetőnek és olvashatónak szánt anyag érthetőségét összevetem egy eredeti, zacskós levesen található elkészítési útmutató leírásának érthetőségével. Munkám során arra a kérdésre kerestem a választ, hogy az értelmileg akadályozott személyek valóban könnyebben értik-e meg a könnyen érthetőnek és olvashatónak szánt, tudatosan kialakított anyagot, mint az - elsősorban a normál fejlődésmenetű személyeknek szánt - eredeti verziót?

Ebben a tanulmányban az elvégzett kutatás módszertanát, az általam készített könnyen érthető anyagokat mutattam be. Az eredményeket Svájcban, a második „Könnyen Érthető Nyelvhasználat Kutatása” konferencián publikálom 2021. augusztus 30-31-én poszter formájában.

\section{Irodalom}

a Fogyatékossággal élő személyek jogairól szóló ENSZ egyezmény, 2006

Boncz I. (2015), Kutatásmódszertani alapismeretek. Pécsi Tudományegyetem Egészségtudományi Kar, Pécs. https://www.etk.pte.hu/protected/OktatasiAnyagok/\%21Palyazati/ sport/Kutatasmodszertan_e.pdf Letöltés ideje: 2020.01.24.

Farkasné Gönczi R. \& Graf-Jaksa É. (2009). Könnyen érthető kommunikáció. In Pandula A., Szatmári P., Vincze T., Farkasné Gönczi R. \& Gráf-Jaksa É. (szerk.), Kommunikációs és információs technológiák és fogyatékosságügy. ELTE Bárczi Gusztáv Gyógypedagógiai Kar, Budapest. 80-100.

Farkasné Gönczi R. (2018). A könnyen érthető kommunikáció fogalma és szabályrendszere nemzetközi és hazai példák, illetve magyar tapasztalati szakértők javaslatai alapján. Gyógypedagógiai Szemle, 46.1:64-76.

Farkasné Gönczi R. (2019). Könnyen érthető kommunikáció - Könnyen érthető élet. http://konynyenertheto.gonczirita.hu/ Letöltés ideje: 2019.12.28.

Günzburg, H. C. (2000). Pedagógiai Analízis és Curriculum a szociális és személyiségfejlődés mérésére értelmi fogyatékos személyeknél. ELTE Bárczi Gusztáv Gyógypedagógiai Főiskolai Kar, Budapest.

Hatos Gy. (2015). Az értelmi akadályozottság értelmezésének változásai. Pedagógiatörténeti Szem/e, 1.1:1-11. http://www.jgypk.hu/pedtort/wp-content/uploads/2014/12/2015_01. pdf Letöltés ideje: 2020.01.29.

Horváth P. L. (2017a). Érthető számodra a világ? Ha nem, tedd érthetőbbé! Carissimi, VIII.5:810.

Horváth P. L. (2017b). Önrendelkezés és könnyen érthető kommunikáció - a KÉK hazai fejlesztésének lehetőségei. In Bogdán B., Cserti-Szauer Cs., Katona V. \& Sándor A. (szerk.), Befogadás és önrendelkezés. Absztraktkötet. ELTE Bárczi Gusztáv Gyógypedagógiai Kar, Budapest. 23-27.

Olvasás-írás kerettanterv a középsúlyosan értelmi fogyatékos tanulók számára 1-8. évfolyam (2020). https://www.oktatas.hu/pub_bin/dload/kozoktatas/kerettanterv/ksni_1_8/Olvasas-iras.doc Letöltés ideje: 2021.03.2.2.

Sántha K. (2009). Bevezetés a kvalitatív pedagógiai kutatás módszertanába. Eötvös József Könyvkiadó, Budapest.

Sutherland, R. J. \& Isherwood, T. (2016). The Evidence for Easy-Read for People With Intellectual Disabilities: A Systematic Literature Review. Journal of Policy and Practice in Intellectual Disabilites, 13.4:297-310. https://doi.org/10.1111/jppi.12201

Szebelédi-Kurucz A. (2012). Farkasné Gönczi Rita: Könnyen érthető konyha. Gyógypedagógiai Szemle, 40.3:286. 


\section{SZÁMÚ MELLÉKLET}

\section{SZÖVEGES-KÉPES KÖNNYEN ÉRTHETŐ RECEPT}

\section{LEVESRECEPT}

HOZZÁVALÓK

1 zacskós levespor

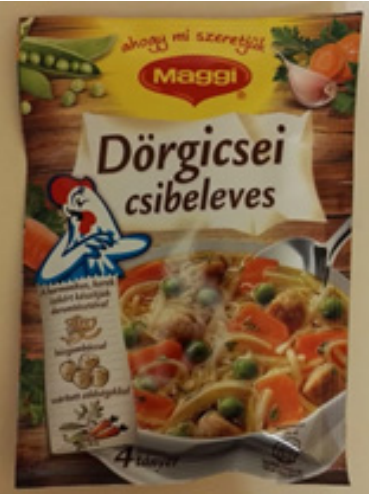

1 liter víz vagyis 1 üveg víz

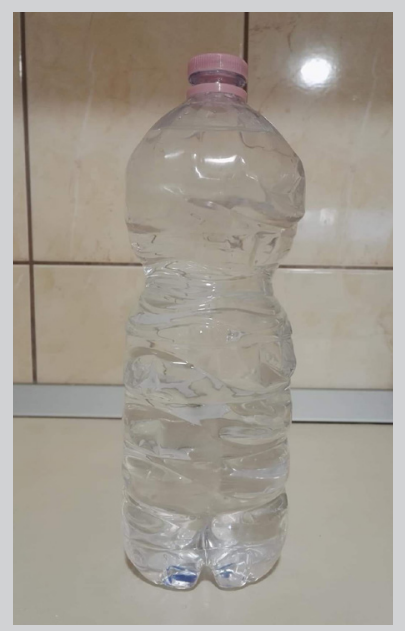


Edény

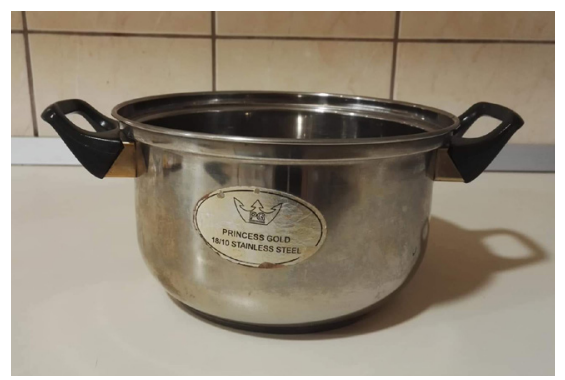

Fakanál

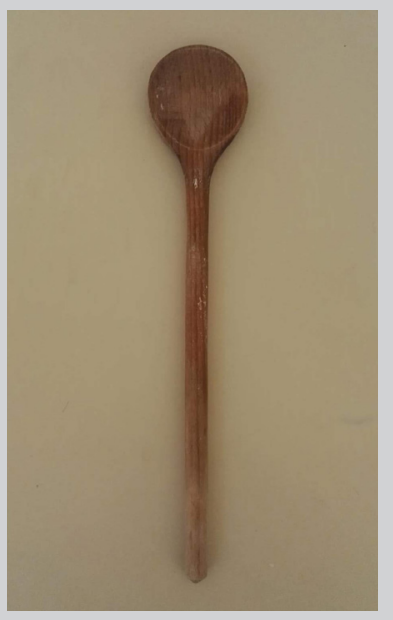

\section{ELKÉSZÍTÉS}

1. Vegyél elő egy edényt.

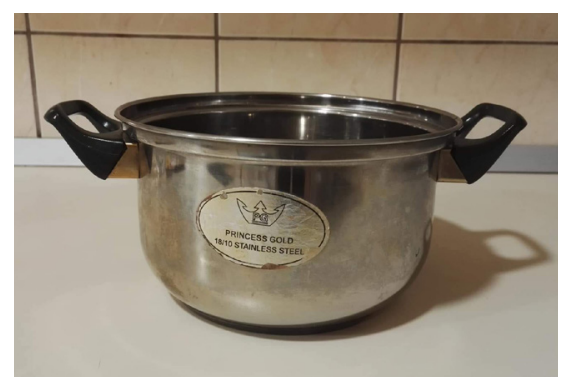


2. Vegyél elő egy üveget.

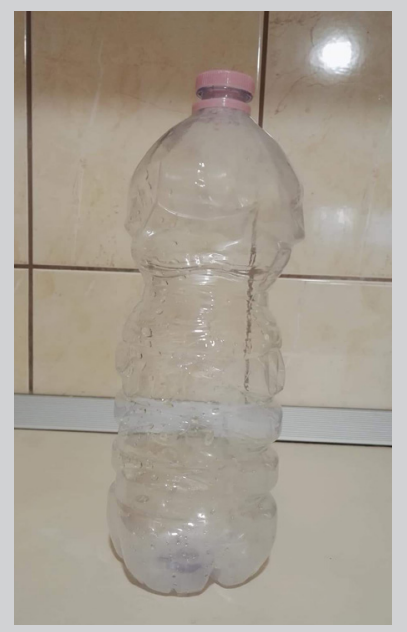

3. Az üveget töltsd meg vízzel.
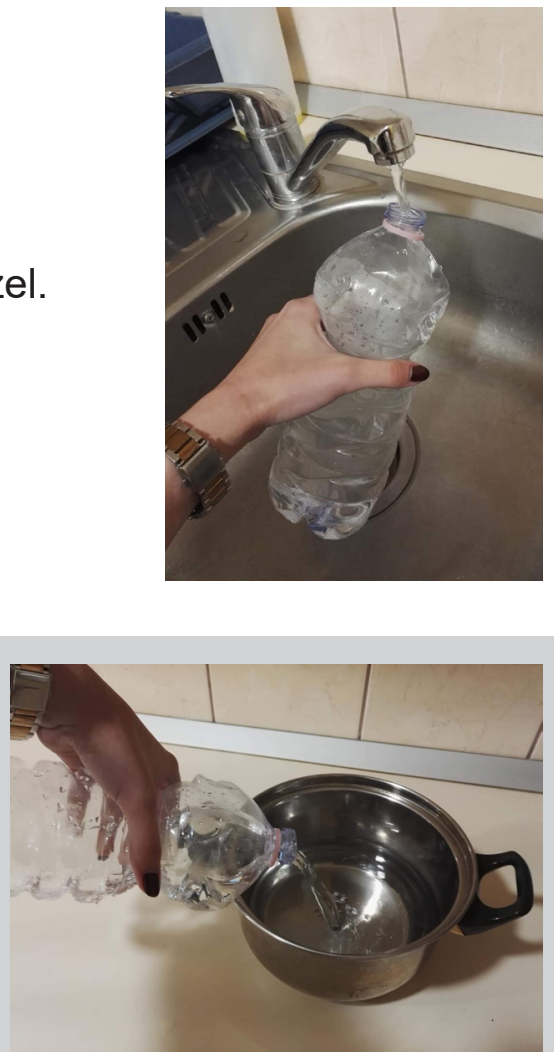

4. A vizet öntsd bele az edénybe. 
5. Ez a tüzhely.

A tüzhelyen főzöl.

A tüzhelyet be kell kapcsolni.

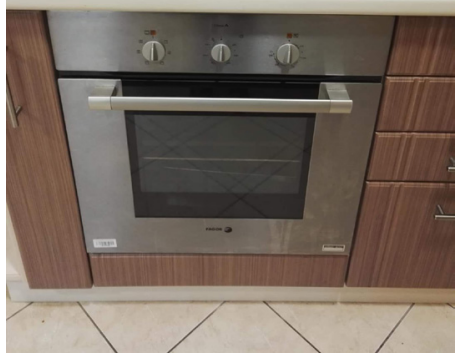

6. A falon van egy csap. A csap így néz ki.

7. Fogd meg a csapot.

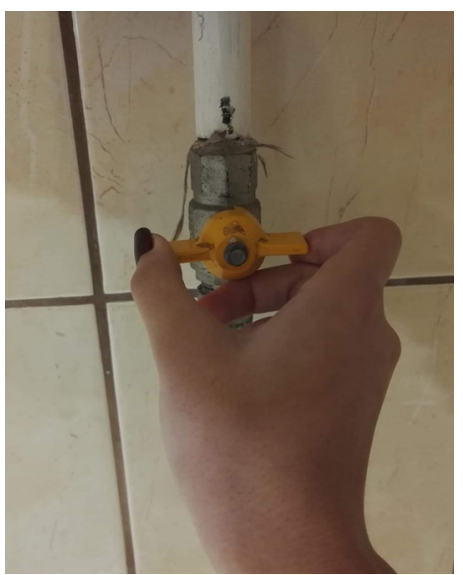


8. Tekerd a csapot lefelé.

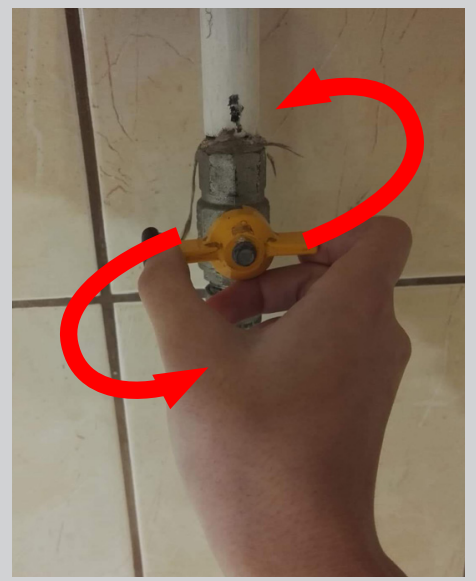

9. Most így néz ki a csap.
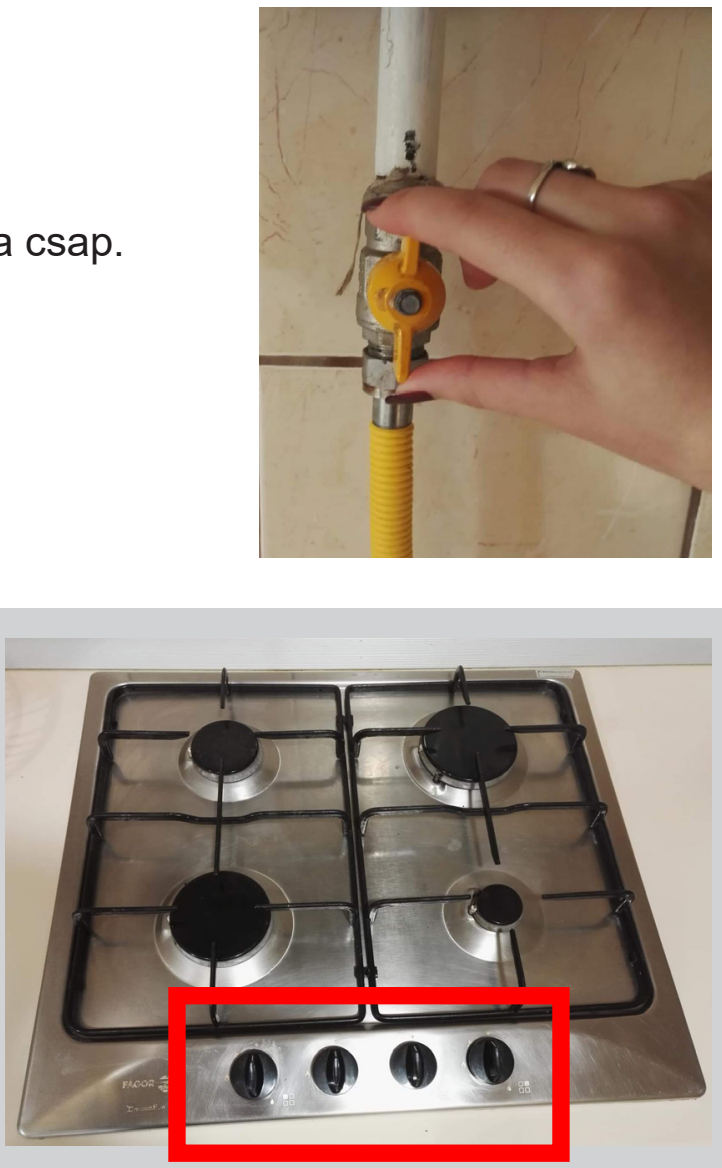

10. A tüzhelyen vannak gombok. 


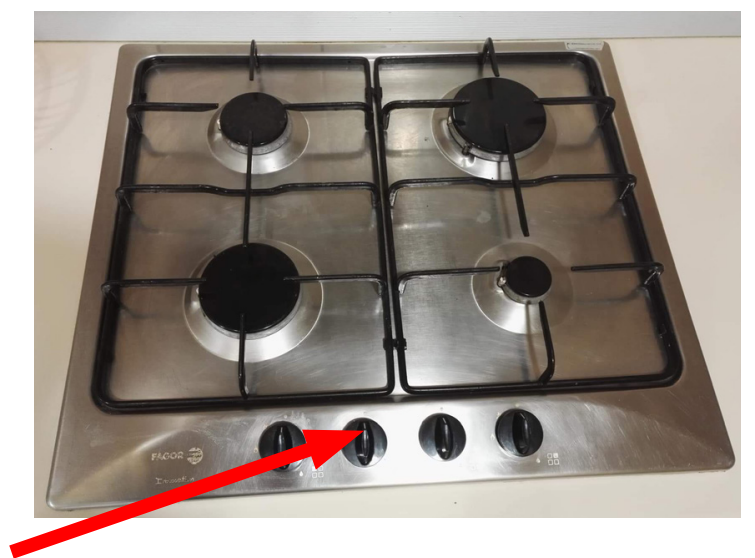

11. Te ezt a gombot használod.

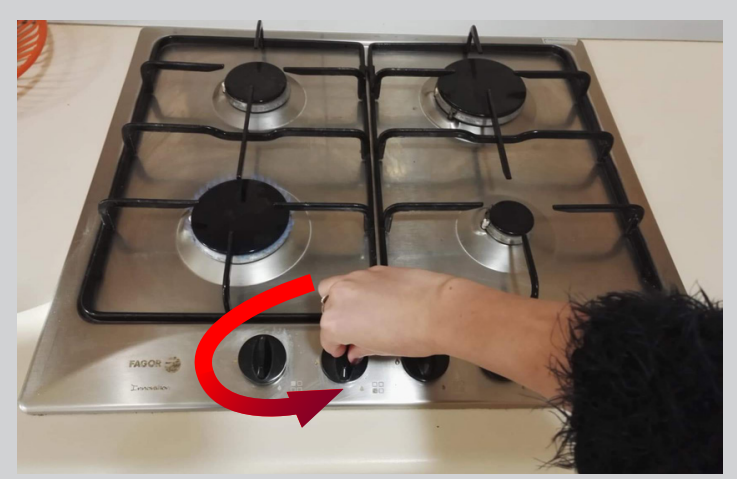

12. Nyomd le a gombot.

Tekerd a gombot lefelé.

13. Most így néz ki a gomb.

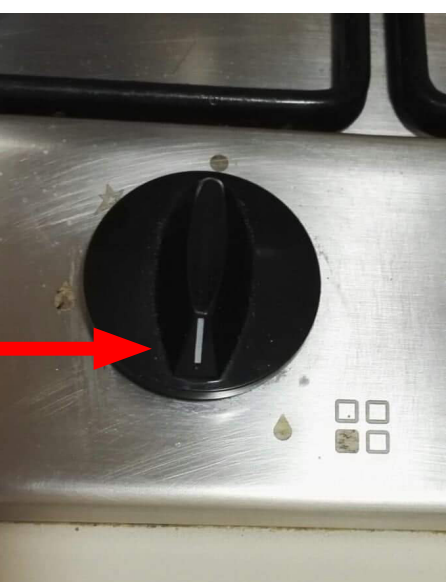


14. Bekapcsoltad a tüzhelyet.
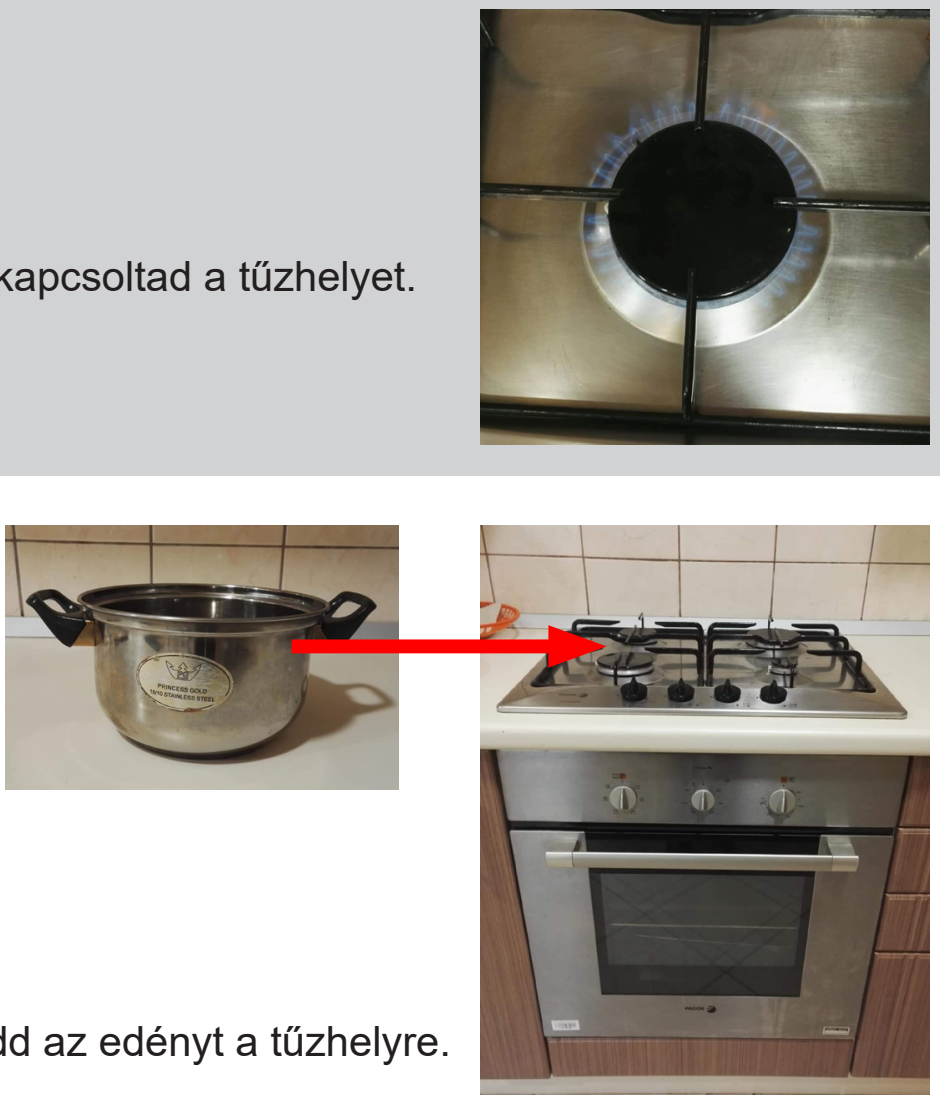

15. Tedd az edényt a tűzhelyre.

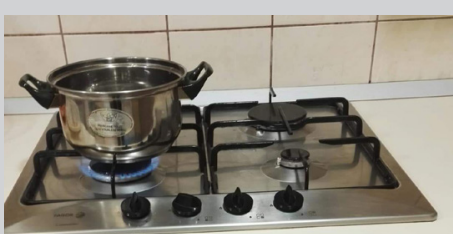

16. Az edény a tủzhelyen van.

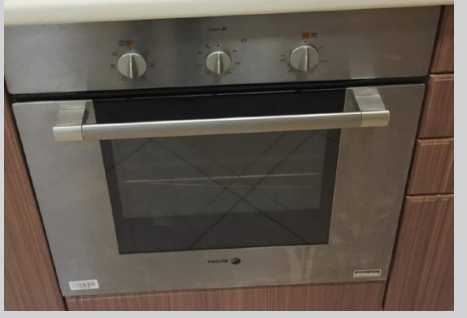


17. Várj, amíg felforr a víz. A felforrás azt jelenti, hogy a víz bugyogni kezd.

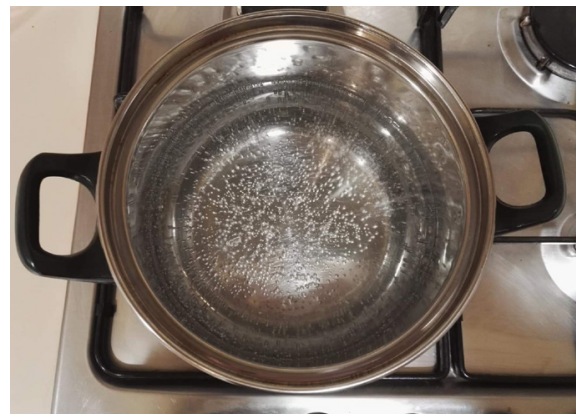

18. Felforrt a víz.

Tépd le a zacskó tetejét.

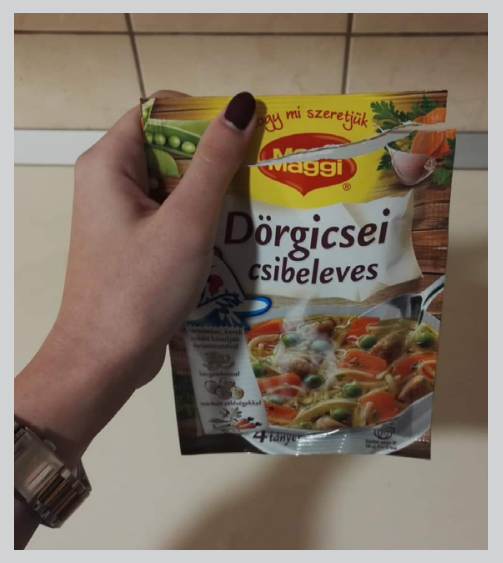

19. A zacskóban levespor van.

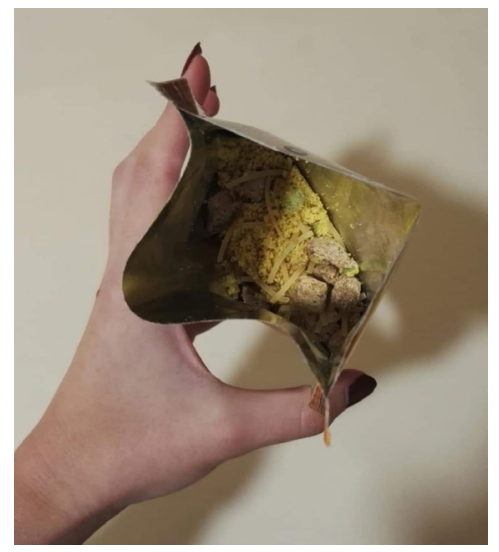


20. Öntsd a levesport az edénybe.

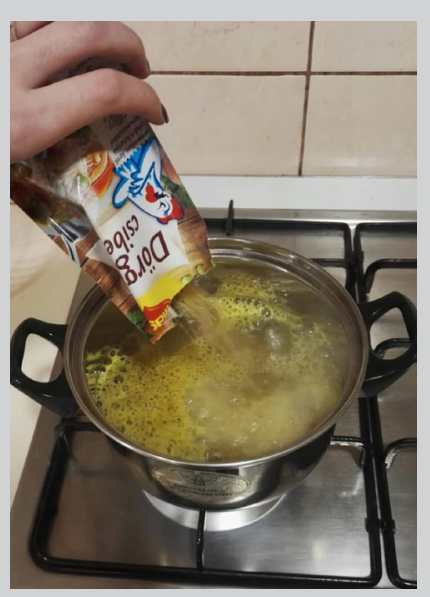

21. 10 percig főzd a levest.
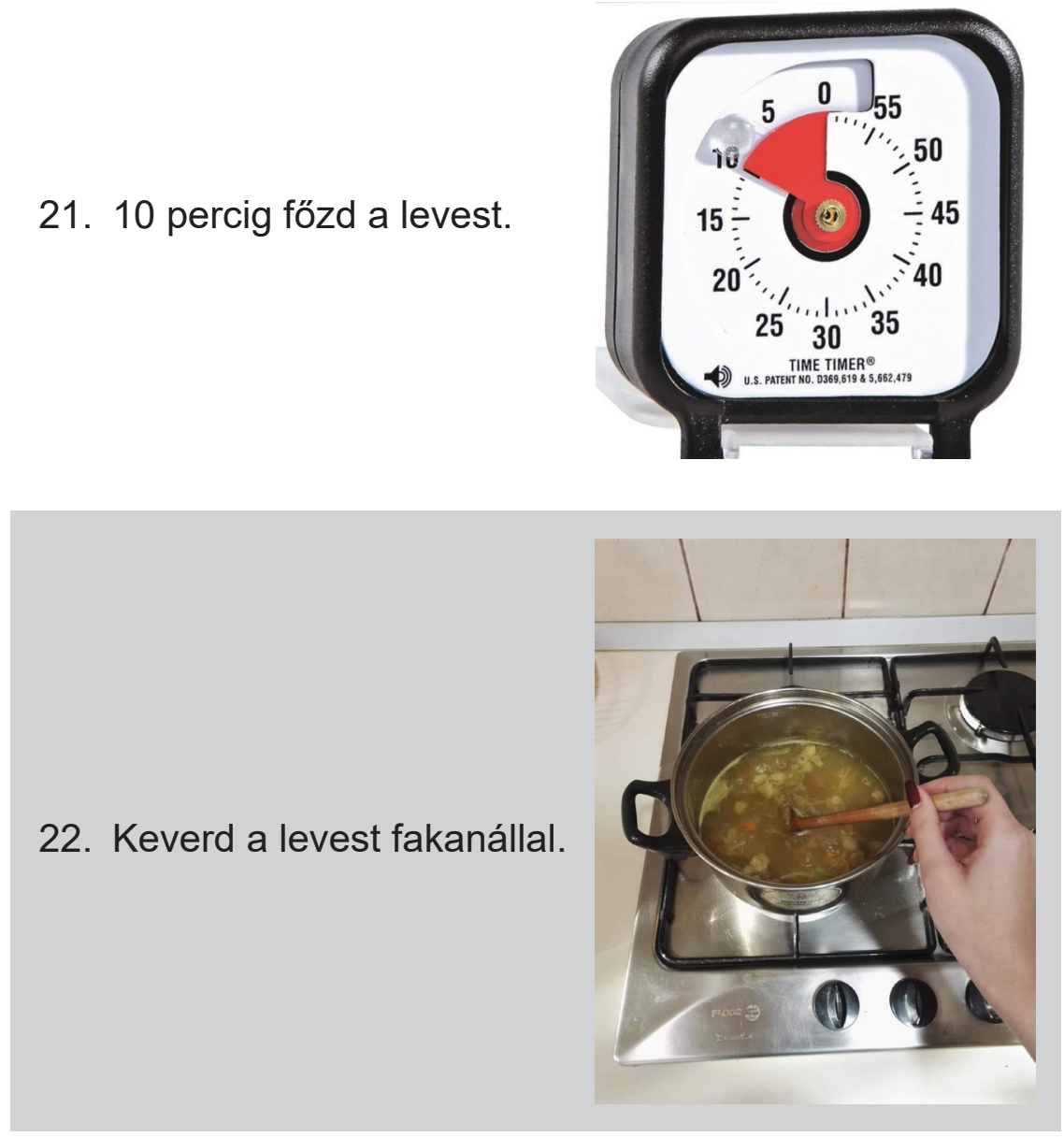
23. A 10 perc eltelt.

Vedd le az edényt a tüzhelyröl.

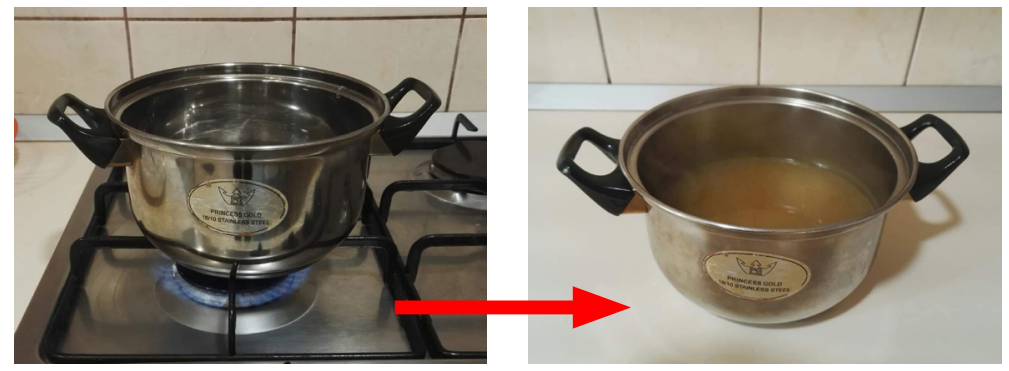

24. Az edényt levetted a tüzhelyröl.

Kész a leves.

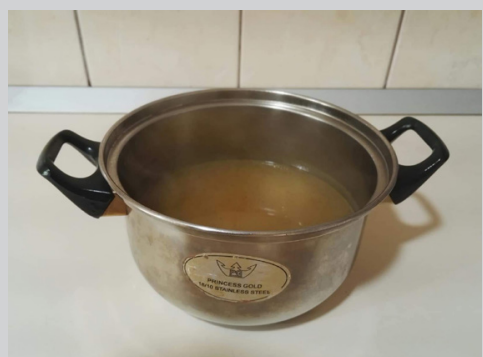

25. Zárd el a tủzhelyet.

Nyomd le a gombot.

Tekerd a gombot felfelé.

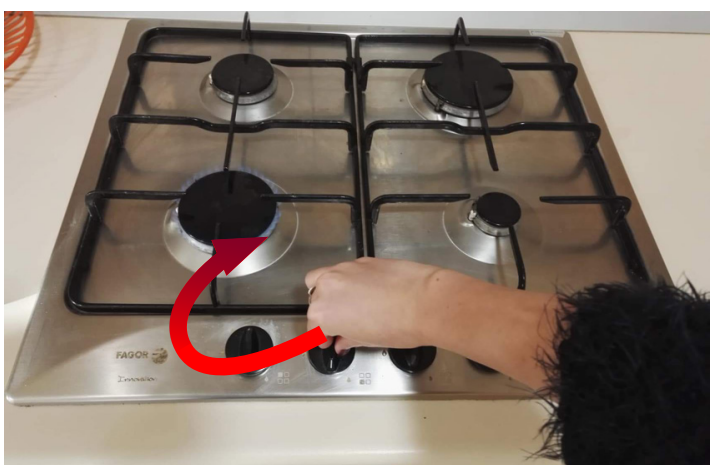




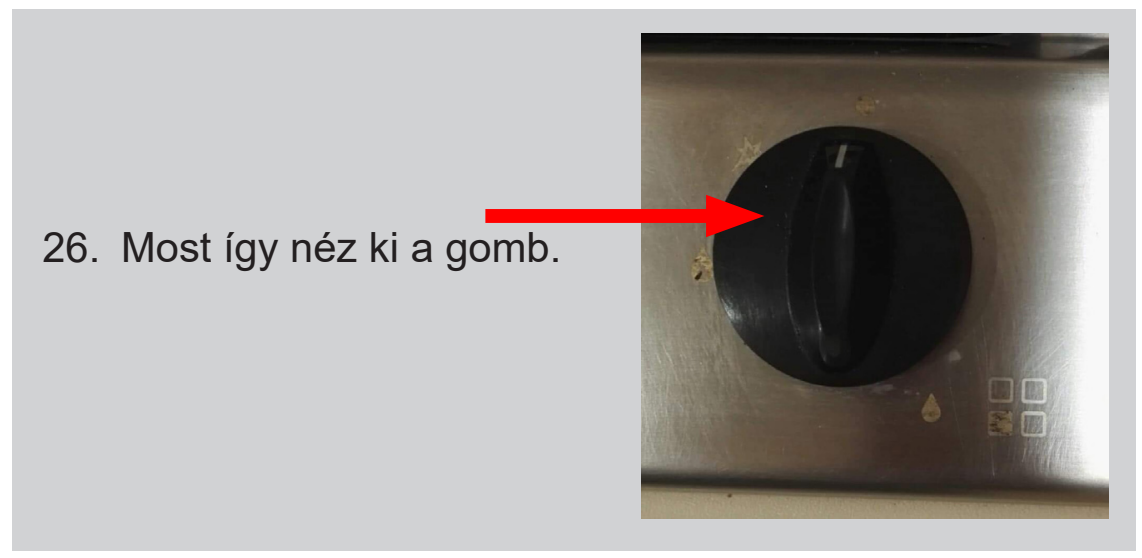

27. Elzártad a tűzhelyet.
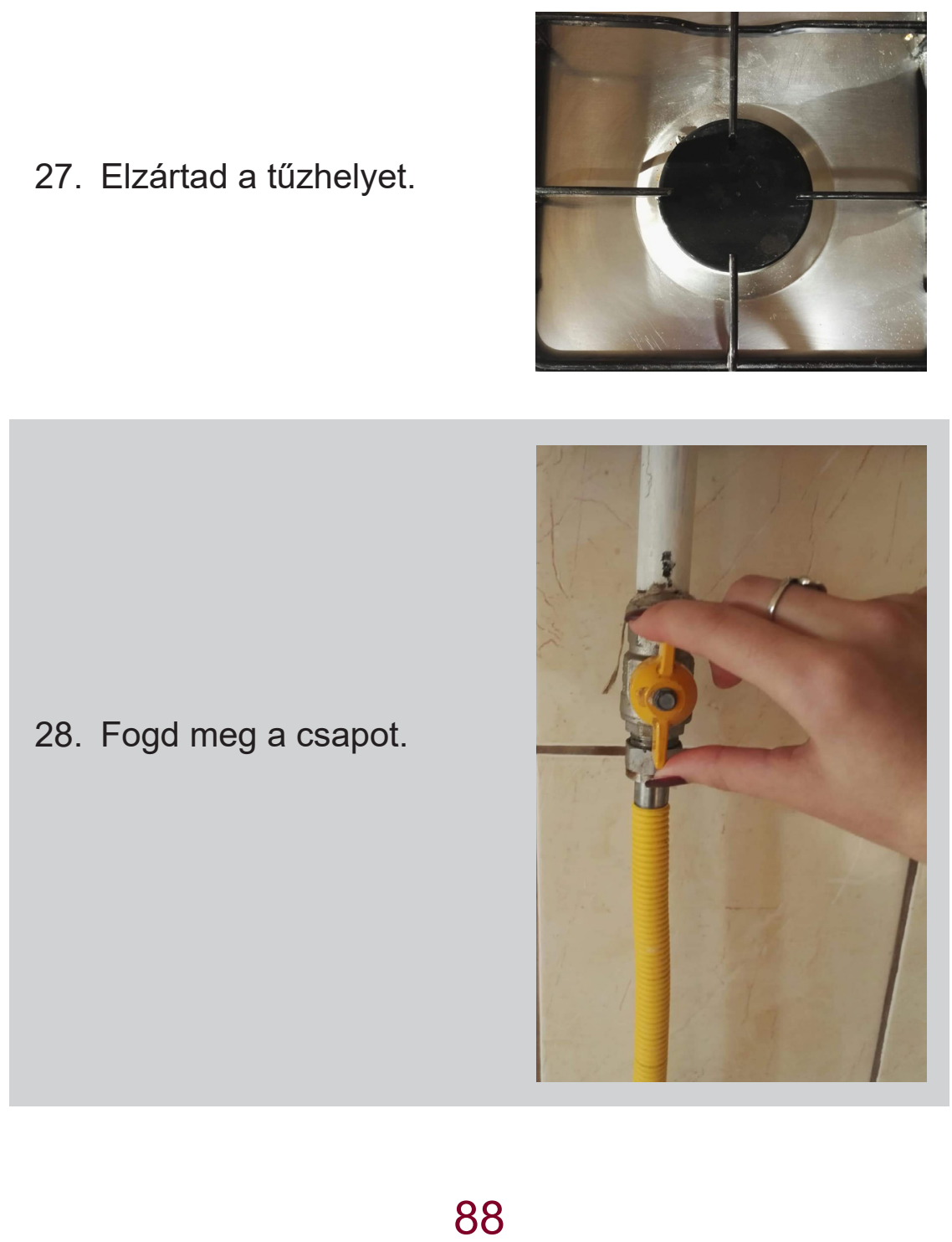
29. Tekerd a csapot felfelé.

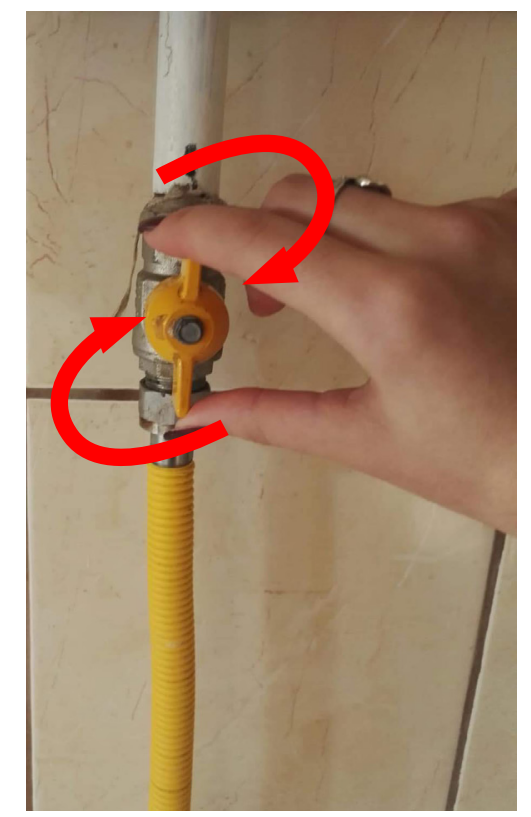

30. Elzártad a csapot.

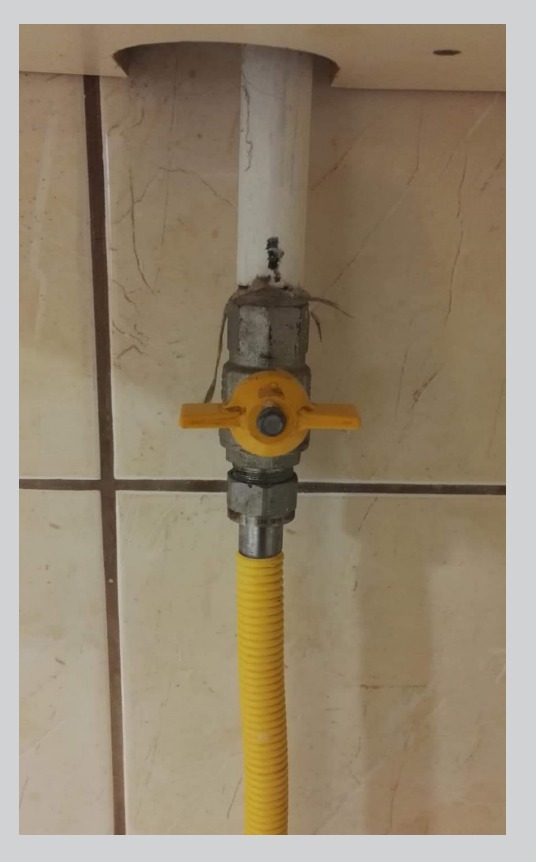




\section{SZÁMÚ MELLÉKLET}

\section{A CSAP HASZNÁLATÁNAK SZÖVEGES-KÉPES LEÍRÁSA}

CSAP HASZNÁLATA

Ez a mosogató.
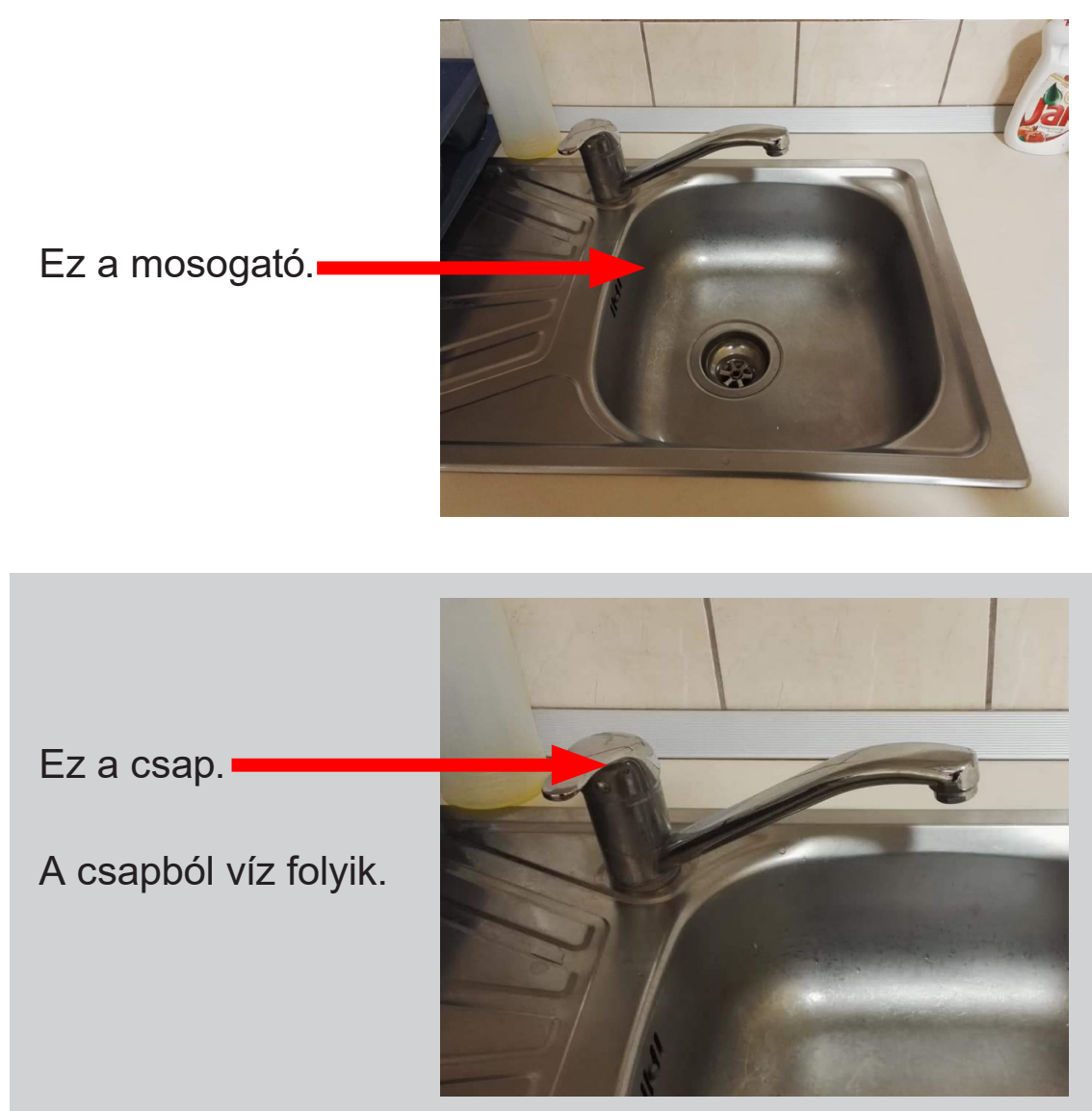
Sokféle csap van.

Én ezt a csapot mutatom meg.

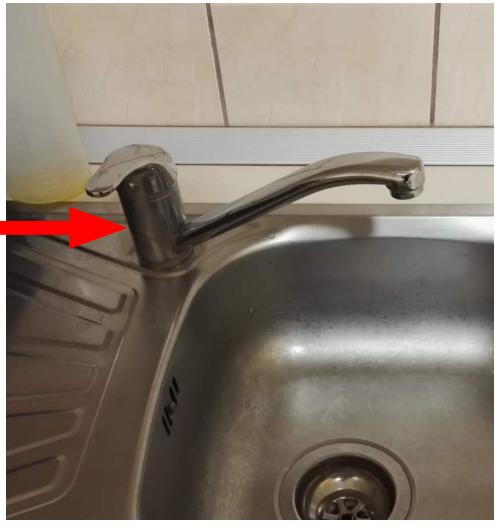

Fogd meg a csap karját.

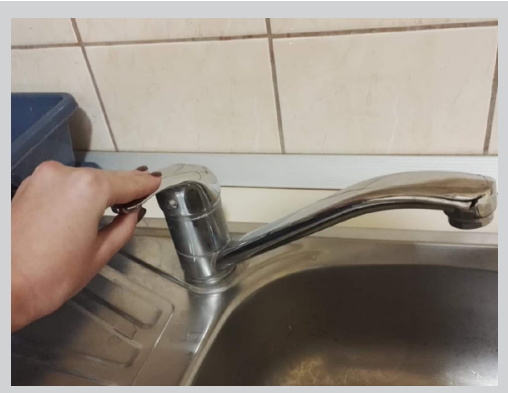

Emeld fel a csap karját.

A víz folyik.
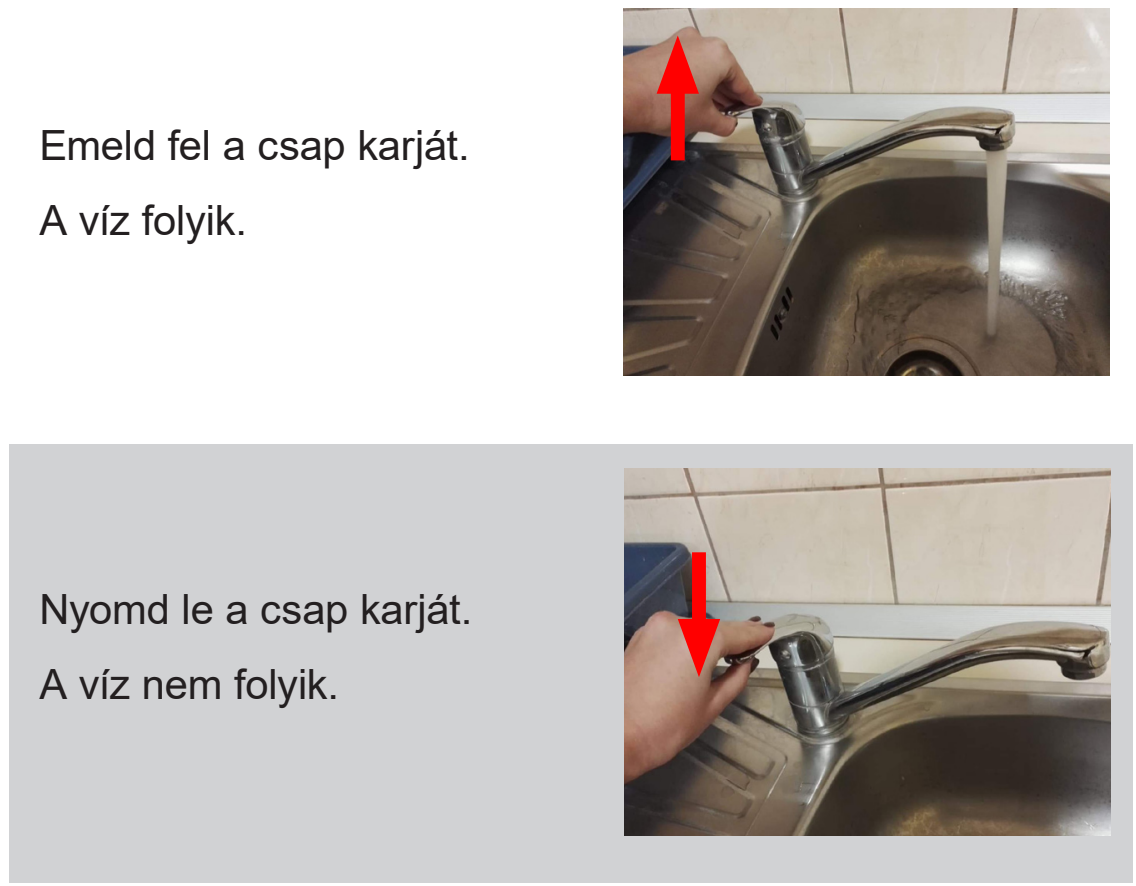